\title{
Effects of Cultivation Years in Protected Vegetable Crop Fields On The Structure and Abundance of Soil nosZ Denitrifying Microbial Community
}

Hui Zhao ( $\square$ yanca0504@163.com )

Tongren University

Zhi-Yong Tan

Tongren University

\section{Research Article}

Keywords: greenhouse vegetable, planting ages, denitrifying microorganism, nosZ gene, community structure

Posted Date: August 20th, 2021

DOI: https://doi.org/10.21203/rs.3.rs-824920/v1

License: (c) (i) This work is licensed under a Creative Commons Attribution 4.0 International License. Read Full License 


\section{Abstract}

The study of the changes in the structure and quantity of the denitrifying microbial community in the protected vegetable crop field is crucial for evaluating the soil quality of long-term protected cultivation and improving the understanding of nitrogen conversion. In this study, quantitative fluorescent PCR was used, with the help of the Illumina Miseq high-throughput sequencing platform, aiming at the nos $Z$ gene, to study the effects of protected cultivation plots $3 \mathrm{a}, 5 \mathrm{a}$, and $7 \mathrm{a}$, and the outdoor cultivation plot (ck) on the structure and quantity of soil denitrifying microbial community. The results demonstrated that the abundance of nos $Z$ gene in ck was significantly higher than the other treatments, and was 1.32, 1.45 and 1.69 times those of Group 3 a, 5 a and 7 a, respectively. As the cultivation year increased, the abundance of nosZ gene was decreased, and the a-diversity index was decreased. The Chao1 index and ACE index of ck were the highest. At the phylum level, the dominant group was Proteobacteria. While at the genus level, the dominant groups were Bradyrhizobium and Achromobacter. The relative abundances of Proteobacteria and Bradyrhizobium were decreased with the increase of protected cultivation time. The principal component analysis (PCA) results showed that the community structure of nos $Z$ varied greatly with the increase of planting time. The community structures of Group 3 a and 5 a were similar, but the community structure of Group 7 a was very different from Group 3 a and $5 \mathrm{a}$. The soil available potassium (AK), ammonium nitrogen and nitrate nitrogen were the primary factors affecting the copy number, a-diversity and community structure of nos $Z$ denitrifying microorganisms. As a conclusion, it can be seen that long-term cultivation of vegetable crops in a protected environment significantly reduced the copy number of nos $Z$ denitrifying microorganisms and had a significant impact on the community structure.

\section{Introduction}

Protected cultivation of vegetable crops is an important branch of the modern intensive agriculture, and is greatly significant for improving natural resource utilization efficiency and boosting farmers'economic benefits. With the growing population and increasing demand for vegetable consumption in China, as well as limited arable land resources, protected cultivation has been dramatically developed in the past 40 years $^{1}$. As of 2016, the protected cultivation area in China had exceeded 58 million mu $(1 \mathrm{mu}=0.165$ acre), ranking first in the world ${ }^{2}$. Currently, protected cultivation production has become a pillar industry in various regions of China. However, protected cultivation has the characteristics of high cropping index, great agricultural investment (such as fungicides, fertilizers, and agricultural films), closed or semi-closed environments with high temperature and high humidity, and no rain leaching. Therefore, the long-term protected cultivation has caused concerns of soil degradation, potential soil and vegetable contamination, and adverse health effects ${ }^{3}$.

Soil microorganisms are one of the essential components of the soil ecosystem. They contribute to energy circulating, nutrient cycling, organic matter conversion, pollutant degradation, and prevention and control of soilborne diseases in the soil ecosystem ${ }^{4}$. Related studies believed that long-term protected 
cultivation had a negative impact on the structure and function of soil microbial community, primarily referring to the community succession from bacteria-dominant to fungi-dominant, and the reduction of the interaction between function-related microbial community members and species, resulting in the replacement of ecologically beneficial microbial community by soilborne pathogens ${ }^{5-8}$. Currently, scholars are more concerned about the overall changes of soil microbial community or targeted microorganisms related to soil-borne diseases. Due to the high degree of structural and functional diversity of soil microorganisms, various types of soil biological processes are driven by the functional groups of microorganisms involved. So far, the response of soil functional microorganisms to long-term vegetable crop production remains poorly understood, especially that of the microorganisms related to nutrient cycling.

Nitrogen $(\mathrm{N})$ is a primary factor limiting plant growth, and soil nitrogen availability plays a crucial role in determining the nitrogen absorption and yield of plants. Nitrogen conversion mainly includes the processes of $\mathrm{N}$ fixation, mineralization, nitrification and denitrification ${ }^{9}$. Among them, denitrification driven by soil microorganisms is an important part of the natural nitrogen cycle and the primary driving force for maintaining the global nitrogen balance. Nitrous oxide $\left(\mathrm{N}_{2} \mathrm{O}\right)$ produced by denitrification is a powerful greenhouse gas and the primary ozone-depleting substance in the atmosphere ${ }^{10}$. It has a global warming potential (GWP) 298 times that of carbon dioxide $\left(\mathrm{CO}_{2}\right)^{11}$. Due to excessive organic fertilizer, nitrogen fertilizer input and flood irrigation, the denitrification in soil was strong, and resulted in a $\mathrm{N}_{2} \mathrm{O}$ emission flux 1.41 times higher than that of the field ${ }^{12}$. Therefore, how to regulate $\mathrm{N} 2 \mathrm{O}$ conversion through microorganisms has become the focus of many scholars ${ }^{13,14}$. Currently, the only known biological process in denitrification is the reduction of $\mathrm{N}_{2} \mathrm{O}$ by the $\mathrm{N}_{2} \mathrm{O}$ reductase encoded by the nos $Z$ gene ${ }^{15}$. The nos $Z$ gene has been used to study the community structure and diversity of denitrifying microorganisms in forests, grasslands and farmlands ${ }^{16,17}$. However, no reports of the impact of longterm protected cultivation on the structure and quantity of nosZ-type denitrifier community in soil are available yet.

Therefore, this study used Illumina MiSeq high-throughput sequencing and real-time PCR to study the structure and abundance of nosZ-type denitrifier communities in soil for various years of protected cultivation. The primary aims of this study were: (1) How will the structure and diversity of the denitrifier community change as the planting time increases in protected cultivation plots? Which dominant community members will change? (2) For the long-term protected cultivation, which soil environmental factors have big impacts on the community structure of denitrifying microorganisms? Our study tried to reveal the denitrification of the protected cultivation in the long-term and provided a scientific basis for indepth understanding of the soil nitrogen cycle of protected cultivation.

\section{Results}

\section{Soil chemical properties}


Long-term protected cultivation of vegetable crops had a significant impact on the chemical properties of the soil (Table 1). The soil pH, soil organic carbon (SOC) and available potassium (AK) contents of all tested cultivation years were all significantly lower than those of the control, decreasing as the cultivation time increasing. The total nitrogen (TN), available phosphorus (AP), ammonium nitrogen $\left(\mathrm{NH}_{4}{ }^{+} \mathrm{N}\right)$ and nitrate nitrogen $\left(\mathrm{NO}_{3}{ }^{-} \mathrm{-}\right)$ of Group $3 \mathrm{a}, 5 \mathrm{a}$ and 7 a were all higher than those of ck. The total nitrogen contents of Group 5a and 7a were significantly increased by $38.26 \%$ and $51.30 \%$ compared with ck, whereas the difference between Group 3 a and ck was not significant. The AP contents of Group 3 a, 5 a and 7 a were respective $2.09,1.62$ and 2.27 times that of AP in ck. The soil ammonium and nitrate nitrogen contents increased by cultivation years, in an order of $7 a>5 a>3 a>c k$.

Table 1

Soil chemical properties with cultivation age of greenhouse vegetables. Diferent letters afer the mean indicate a signifcant diference between treatments.

\begin{tabular}{|c|c|c|c|c|c|c|c|}
\hline Treatments & $\mathrm{pH}$ & $\begin{array}{l}\text { SOC } \\
\left(\mathrm{g} \mathrm{kg}^{-1}\right)\end{array}$ & $\begin{array}{l}\mathrm{TN}(\mathrm{g} \\
\left.\mathrm{kg}^{-1}\right)\end{array}$ & $\begin{array}{l}\mathrm{AP}(\mathrm{mg} \\
\left.\mathrm{kg}^{-1}\right)\end{array}$ & $\begin{array}{l}\mathrm{AK}(\mathrm{mg} \\
\left.\mathrm{kg}^{-1}\right)\end{array}$ & $\begin{array}{l}\mathrm{NH}_{4}{ }^{+}-\mathrm{N} \\
\left(\mathrm{mg} \mathrm{kg}^{-}\right. \\
\left.{ }^{1}\right)\end{array}$ & $\begin{array}{l}\mathrm{NO}_{3}{ }^{-}-\mathrm{N} \\
\left(\mathrm{mg} \mathrm{kg}^{-}\right. \\
\left.{ }^{1}\right)\end{array}$ \\
\hline ck & $\begin{array}{l}6.22 \pm \\
0.03 a\end{array}$ & $\begin{array}{l}23.35 \pm \\
0.33 a\end{array}$ & $\begin{array}{l}1.15 \pm \\
0.05 \mathrm{c}\end{array}$ & $\begin{array}{l}13.83 \pm \\
1.28 \mathrm{c}\end{array}$ & $\begin{array}{l}215.23 \pm \\
3.08 a\end{array}$ & $\begin{array}{l}7.66 \pm \\
0.36 \mathrm{~d}\end{array}$ & $\begin{array}{l}8.43 \pm \\
0.77 \mathrm{~d}\end{array}$ \\
\hline $3 a$ & $\begin{array}{l}5.52 \pm \\
0.27 b\end{array}$ & $\begin{array}{l}21.49 \pm \\
0.64 \mathrm{~b}\end{array}$ & $\begin{array}{l}1.2 \pm \\
0.02 \mathrm{c}\end{array}$ & $\begin{array}{l}28.91 \pm \\
1.81 \mathrm{ac}\end{array}$ & $\begin{array}{l}176.51 \pm \\
8.24 b\end{array}$ & $\begin{array}{l}14.48 \pm \\
1.27 \mathrm{c}\end{array}$ & $\begin{array}{l}18.76 \pm \\
1.38 \mathrm{c}\end{array}$ \\
\hline $5 a$ & $\begin{array}{l}4.82 \pm \\
0.04 c\end{array}$ & $\begin{array}{l}20.85 \pm \\
0.29 \mathrm{bd}\end{array}$ & $\begin{array}{l}1.59 \pm \\
0.04 \mathrm{~b}\end{array}$ & $\begin{array}{l}22.38 \pm \\
0.68 \mathrm{~b}\end{array}$ & $\begin{array}{l}130.91 \pm \\
3.13 c\end{array}$ & $\begin{array}{l}17.74 \pm \\
1.37 \mathrm{~b}\end{array}$ & $\begin{array}{l}24.39 \pm \\
1.34 \mathrm{~b}\end{array}$ \\
\hline $7 a$ & $\begin{array}{l}4.53 \pm \\
0.06 \mathrm{c}\end{array}$ & $\begin{array}{l}17.75 \pm \\
0.33 c\end{array}$ & $\begin{array}{l}1.74 \pm \\
0.05 a\end{array}$ & $\begin{array}{l}31.42 \pm \\
0.42 \mathrm{a}\end{array}$ & $\begin{array}{l}87.25 \pm \\
2.08 d\end{array}$ & $\begin{array}{l}21.56 \pm \\
1.07 a\end{array}$ & $\begin{array}{l}30.67 \pm \\
2.33 a\end{array}$ \\
\hline
\end{tabular}

nosZ gene abundance

The range of nos $Z$ gene copy number with different years of cultivation was $5.19 \times 10^{6} \sim 8.78 \times 10^{6}$ copies/g soil (Fig. 1). The copy numbers of nos $Z$ gene in groups with various years of protected cultivation were significantly less than ck, whose number was respective 1.32, 1.45 and 1.69 times that of Group 3 a, 5 a and $7 \mathrm{a}$. There was no significant difference in the copy number of nos $Z$ gene between Group 3 a, 5 a and $7 \mathrm{a}$, and the copy number was decreasing as cultivation time increased. The correlation analysis of nos $Z$ gene abundance and soil chemical properties revealed that the nos $Z$ gene abundance had significant positive correlations with soil pH and SOC, highly significant negative correlations with soil TN, ammonium nitrogen and nitrate nitrogen, a significant negative correlation with AP, and a highly significant positive correlation with AK (Fig. 2). 
The cultivation year had a significant impact on the Chao1 index and ACE index of the nosZ community, and it had a highly significant impact on the Shannon's index and the Simpson's index (Table 2). The Chao1 index and ACE index displayed the same trend, ranging from 1,057.51 1,423.84 and 1,070.06 $1,429.96$, respectively. Both indices for various protected cultivation years were smaller than those of ck, decreasing as cultivation time increased. Group 7 a had significantly smaller values compared to all other treatments. The ranges of the Shannon's index and Simpson's index were $6.2 \sim 7.02$ and $0.82 \sim 0.86$, respectively, with Group 7 a significantly smaller than the other treatments. The Shannon's index was the highest in Group $3 \mathrm{a}$, in an order of $3 \mathrm{a}>\mathrm{ck}>5 \mathrm{a}>7 \mathrm{a}$. The Simpson's index was the highest in Group 5a, in an order of $5 \mathrm{a}>3 \mathrm{a}>\mathrm{ck}>7 \mathrm{a}$.

Table 2

\diversity index of nosZ-type denitrifying bacterial community with cultivation age of greenhouse vegetables. Diferent letters afer the mean indicate a signifcant diference between treatments.

\begin{tabular}{|lllll|}
\hline Treatments & Chao1 index & ACE index & Shannon index & Simpson index \\
\hline $\mathrm{ck}$ & $1423.84 \pm 65.53 \mathrm{a}$ & $1429.96 \pm 60.49 \mathrm{a}$ & $7.02 \pm 0.08 \mathrm{a}$ & $0.84 \pm 0.01 \mathrm{~b}$ \\
\hline $3 \mathrm{a}$ & $1358.68 \pm 73.93 \mathrm{a}$ & $1366.93 \pm 77.77 \mathrm{a}$ & $7.18 \pm 0.24 \mathrm{a}$ & $0.85 \pm 0.02 \mathrm{ab}$ \\
\hline $5 \mathrm{a}$ & $1305.4 \pm 97.92 \mathrm{ac}$ & $1312.08 \pm 98.23 \mathrm{ac}$ & $6.96 \pm 0.10 \mathrm{ac}$ & $0.86 \pm 0.01 \mathrm{a}$ \\
\hline $7 \mathrm{a}$ & $1057.51 \pm 154.83 \mathrm{~b}$ & $1070.06 \pm 157.58 \mathrm{~b}$ & $6.2 \pm 0.32 \mathrm{~b}$ & $0.82 \pm 0.02 \mathrm{c}$ \\
\hline
\end{tabular}

The Chao1 index and the ACE index were both highly significantly positively correlated with soil pH, SOC and $\mathrm{AK}$, and significantly negatively correlated with $\mathrm{TN}, \mathrm{AP}$, ammonium nitrogen and nitrate nitrogen. The Shannon's index was significantly positively correlated with SOC, highly significantly negatively correlated with $\mathrm{TN}$, and significantly negatively correlated with ammonium nitrogen and nitrate nitrogen (Fig. 2).

\section{nosZ community composition}

By classifying the nosZ community OTUs obtained from the samples, a total of six classes were obtained at the phylum level, including Proteobacteria, Bacteria_unidentified, Gemmatimonadetes, Bacteroidetes, Acidobacteria and Chloroflexi (Fig. 3). The relative abundances of soil Proteobacteria, Bacteria_unidentified, Acidobacteria and Chloroflexi were significantly different for treatments with different years of protected cultivation. The Proteobacteria, Bacteria_unidentified and Gemmatimonadetes were the dominant phyla, with relative abundance ranges of $62.27 \sim 70.42 \%, 16.66$ $\sim 25.19 \%$ and $2.88 \sim 3.82 \%$, respectively. The relative abundances of Proteobacteria in Group 5a and 7a were less than that of ck, lowered by $2.69 \%$ and $10.34 \%$, respectively. The relative abundance of Bacteria_unidentified was the highest in Group 7 a, significantly higher than that of Group 3 a and 5 a. The relative abundance of Gemmatimonadetes was the highest in Group 3a and the lowest in Group 5 a, in an order of $3 a>7 a>c k>5 a$. The protected cultivation exerted an inhibitory effect on the Proteobacteria phylum, and the inhibition was increased with the increase of the cultivation time. 
A total of ten classes were obtained at the genus level with those with an average relative abundance of $<1 \%$ classified into one group (Fig. 4), including Bradyrhizobium, Bacteria_unidentified, Achromobacter, Aromatoleum, Gemmatimonas, Ochrobactrum, Azoarcus, Azospirillum, Mesorhizobium and Rhodopseudomonas. Among them, significant differences in the relative abundance of Bradyrhizobium, Bacteria_unidentified, Achromobacter and Rhodopseudomonas were seen in the protected cultivations for different years. The Bradyrhizobium, Bacteria_unidentified and Achromobacter were the dominant genera, with relative abundance ranges of $39.01 \sim 47.68 \%, 18.48 \sim 27.68 \%$ and $5.28 \sim 8.57 \%$, respectively. The relative abundance of Bradyrhizobium in various protected cultivation groups was higher than that of ck, respective 1.23, 1.12 and 1.07 times that of $c k$, in an order of $3 a>5 a>7 a>c k$. The relative abundance of Achromobacterwas significantly lower in Group 7a than the other treatments, in an order of $5 \mathrm{a}>\mathrm{ck}>3$ a $>7$ a. The relative abundance of Aromatoleum was increased with the protected cultivation time increase, and the values of both Group 3 a and 5 a were lower than ck.

\section{nosZ community structure and its relationship with soil chemical properties}

Clustering analysisBy the PCA conducted for the nos $Z$ community, it can be seen that the structure of the nosZ community in the soils with various protected cultivation years was significantly different (Fig. 5). The first and second principal components interpreted $48.41 \%$ and $21.53 \%$ of the bacterial community structure variation, respectively, giving a cumulative contribution rate of $69.94 \%$. Group 7 a was far from Group 3 a and 5 a on PC1 and PC2, indicating a large change of nos $Z$ community structure as the cultivation time extended. Group 3 a and 5 a were close, indicating a high community similarity.

The redundancy analysis of nos $Z$ community structure and soil chemical indicators were performed (Fig. 6). The physical and chemical properties of soil could explain $46.61 \%$ of all the information on the first axis and $22.44 \%$ on the second axis for the nos $Z$ community, giving a number of $69.05 \%$ total information explained by the two axes. The SOC and nitrate nitrogen had significant impacts on the nos $Z$ community structure. The soil AP, AK and ammonium nitrogen had highly significant effects on nos $Z$ community structure.

\section{Discussion}

Long-term protected cultivation of vegetable crops had a significant impact on soil chemical indicators. The TN, ammonium nitrogen and nitrate nitrogen were all increased significantly with the increase of protected cultivation time, and all of them were higher than ck. This may be due to that the intensive planting, continuous high fertilizer input and long-term continuous cropping of protected cultivation restricted the growth of vegetable crops, hindered their nutrient absorption, and thus most of the nutrients accumulated in the soil over time ${ }^{18,19}$. This study demonstrated that the SOC contents of various protected cultivation years were all lower than ck, decreasing year by year. This was contrary to the results of previous studies ${ }^{20,21}$, but similar to the results of Song et al ${ }^{22}$. It may be due to the small amount of organic fertilizer applied and a small return of plant residues to soil in this area. In this study, the soil $\mathrm{pH}$ value was decreased as the cultivation year increased, consistent with the results of various 
studies ${ }^{23,24}$. Presumably, it is because of the soil acidification caused by the accumulation of $\mathrm{SO}_{4}{ }^{2-}$ and $\mathrm{NO}_{3}{ }^{-}$from long-term excessive application of (nitrogen) fertilizers.

Denitrification is an important part responsible for soil nitrogen loss, greenhouse gas $\mathrm{N}_{2} \mathrm{O}$ emission and $\mathrm{N}_{2}$ conversion. Denitrification is primarily driven by microorganisms and is closely related to soil fertilization ${ }^{25}$. In this study, the copy numbers of nos $Z$ in the soil for various protected cultivation years were all significantly less than that of ck, and the copy number of nos $Z$ was decreasing with the extension of planting time. It may be due to the high water and fertilizer input of protected cultivation that the reduction of $\mathrm{N}_{2} \mathrm{O}$ by soil microorganisms was declined in greenhouses ${ }^{26}$. Bergaust et al.found that the $\mathrm{N}_{2} \mathrm{O}$ reductase of Paracoccus was difficult to assemble at a lower $\mathrm{pH}$, ultimately leading to a decrease in the enzyme activity. ${ }^{27}$ Hallin et al. believed that the copy number of nos $Z$ gene dropped rapidly with increased nitrogen fertilizer application rate ${ }^{25}$. In this study, the nos $Z$ gene abundance had significant positive correlations with soil pH and SOC. Because denitrifying microorganisms are generally chemical heterotrophs, they need substances like organic matter as energy sources ${ }^{28}$. The study conducted by Matlou and Haynes showed that SOC was closely related to soil microbial community structure, and organic carbon was the necessary substrate and energy source for soil microbial activities ${ }^{29}$. In our study, the SOC content was decreasing with the increase of protected cultivation time, and thus it could not provide a sufficient energy source for denitrifiers. Bowden et al. believed that the accumulation of SOC was due to the reduction of microbial biomass ${ }^{30}$. Soil $\mathrm{pH}$ is the primary environmental factor responsible for variations in the number of denitrifying microorganisms ${ }^{31}$. As the protected cultivation time increased, the soil pH kept decreasing. Soil acidification causes the accumulation of iron and aluminum. Iron and aluminum hydroxides can reduce the utilization of carbon sources by microorganisms via adsorbing soil soluble carbons ${ }^{32}$. The stronger the soil acidity, the greater the accumulation of $\mathrm{Al}^{3+}$, and the severer the damage to the soil bacterial cell membrane ${ }^{33}$. The research by Bauhus and Khanna showed that the addition of phosphorus promoted soil denitrification in acid forest soils ${ }^{34}$. In this study, the copy number of nosZ gene was significantly correlated with AP, further supporting the regulation of soil phosphorus on denitrifiers. Nevertheless, the mechanism of how phosphorus regulates the growth of denitrifying microorganisms remains elusive. Nitrate nitrogen can serve as the substrate of denitrifiers and the electron acceptor in denitrification, thus affects the growth of denitrifying microorganisms ${ }^{35}$. The results of this study showed that the abundance of nos $Z$ gene was highly significantly negatively correlated with soil TN, ammonium nitrogen and nitrate nitrogen. Comprehensive analysis suggested that changes in soil $\mathrm{pH}$ and nitrogen content were the primary factors driving the changes in nos $Z$ gene copy number.

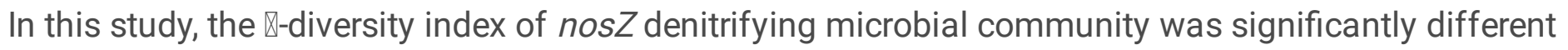
among different treatments. Both Chao1 and ACE indexes were the highest in ck, and gradually decreased with the extension of planting time. It may be due to the long-term protected cultivation that the soil acidification and salinization became severer, resulting in decreased abundance of soil denitrifier species. The Shannon's and Simpson's indices were higher in Group 3a and lower in Group 7a, indicating decreased soil denitrifying microbial species diversity with the planting time extension. It may be that the 
long-term protected cultivation led to a decrease in SOC content, which then could not provide the necessary carbon source for the growth of denitrifiers.

The dominant group of nos $Z$ denitrifiers was exclusively Proteobacteria, consistent with the results of many studies ${ }^{36}$. The abundance of soil Proteobacteria can represent the nutrient level including soil organic matter to a certain extent, and Proteobacteria favor a higher $\mathrm{pH}$ soil environment ${ }^{37}$. In this study, the abundance of Proteobacteria showed a decreasing trend with the extension of planting time, and was the highest in ck and Group 3a. It may be related to the high soil nutrient content and high $\mathrm{pH}$ that are beneficial to the growth of Proteobacteria. At the genus level, the common dominant group was Brachyrhizobium, whose relative abundance accounted for $43 \%$ of the nos $Z$ gene sequences on average. The relative abundances of Brachyrhizobium in Group 3a, 5a and 7a were all higher than ck, and it was decreasing with the extension of planting time. According to the PCA results, the nos $Z$ community was clustered clearly, and Group 7a was well separated from Group 3a and 5a, while the latter two were clustered relatively closely. It indicated that the nos $Z$ community structure varied greatly with the planting time increase for the protected cultivation field.

Related researchers believe that the difference in the response of denitrifiers to fertilization is shown in soil $\mathrm{pH}, \mathrm{TN}$, ammonium nitrogen and nitrate nitrogen ${ }^{25}$. Soil $\mathrm{pH}$ is considered to be the primary factor affecting the community structure of denitrifying microorganisms. pH can exert a selective effect on denitrifiers, and its variation can affect the community structure of denitrifying microorganisms and further affect their response to environmental changes ${ }^{31}$. In this study, soil pH was significantly different in the protected cultivations for different years. In addition, soil pH was significantly correlated with the relative abundance of nos $Z$, indicating soil pH as the primary cause of changes in denitrifying microbial community structure. Usually, the SOC, ammonium nitrogen and nitrate nitrogen serve as direct or indirect substrates and energy sources for denitrifying microorganisms, and they may affect the community structure of soil denitrifiers. Nitrate nitrogen is the substrate of denitrification, and its content directly affects the utilization of nitrogen by denitrifying microorganisms ${ }^{38}$.

In conclusion, the nos $Z$ gene abundance, Chao 1 index and ACE index demonstrated the same trends that decreased as the protected cultivation time increased. The abundance of nos $Z$ gene was not significantly different in different protected cultivation years. At the phylum level, Proteobacteria was the dominant group, and the most abundant in Group 3 a. At the genus level, Bradyrhizobium and Achromobacter were dominant groups. The relative abundance of Bradyrhizobium was decreased as the protected cultivation time increased, but was all higher than that of ck. The relative abundance of Achromobacter was the highest in Group $5 \mathrm{a}$, showing a " $\mathrm{V}$ " trend as the protected cultivation time increased. The total nitrogen, available potassium, ammonium nitrogen and nitrate nitrogen had great impacts on nos $Z$ gene abundance, a-diversity index and community structure. It can be seen that nitrogen fertilizer was an important factor limiting the fast-growing and high-yield of vegetables in protected cultivation fields. Soil nitrogen is conducive to vegetable crop absorption and utilization, and can directly or indirectly regulate the denitrifying microbial community. 


\section{Materials And Methods}

\section{Site Description and Soil Sampling}

The study area was located in Heping Town, Tongren City, Guizhou Province, China. It has a subtropical monsoon climate with an average annual temperature of $18{ }^{\circ} \mathrm{C}$, an annual precipitation of $1,313 \mathrm{~mm}$, and a yellow soil type. Three greenhouses with different planting years were selected as the experimental groups, and the nearby outdoor plot was used as a control (ck). For greenhouse plots, the fertilizers applied included a base fertilizer of $80-100 \mathrm{~kg} / 667 \mathrm{~m}^{2}$ of compound NPK (Nitrogen, Phosphorus and Potassium) fertilizer, and a topdressing of nitrogen fertilizer of $40-50 \mathrm{~kg} / 667 \mathrm{~m}^{2}$. For the outdoor plot, the fertilizers applied were $40-50 \mathrm{~kg} / 667 \mathrm{~m}^{2}$ of base fertilizer and $20-30 \mathrm{~kg} / 667 \mathrm{~m}^{2}$ of topdressing. The main planted vegetables were eggplants, cucumbers, zucchini, and cowpeas. The samples were collected in July 2017. The 0-10 cm top-soils were sampled following an "S" shape using the five-point sampling method in each plot, mixed as one soil sample, stored in an ice box and transported to the laboratory as soon as possible. After removing stones and roots, the soil sample was passed through a 2-mm sieve. The prepared soil sample was then divided into three parts, one part of fresh soil was used for the determination of ammonium nitrogen and nitrate nitrogen, one part was stored in a $-80{ }^{\circ} \mathrm{C}$ freezer for the analysis of nos $Z$ community structure and abundance, and one part was used for the determination of soil chemical indicators after air-dried indoors and sieved.

\section{Soil Physicochemical Analysis}

Soil $\mathrm{pH}$ was measured by the potentiometry method. Soil organic carbon content (SOC) was measured via the potassium dichromate oxidation method. Soil total nitrogen (TN) was determined via Kjeldahl method; Soil available phosphorus (AP) was measured via sodium bicarbonate extraction-molybdenum antimony colorimetric. Soil available potassium (AK) was measured via ammonium acetate extractionflame photometry. Soil ammonium nitrogen $\left(\mathrm{NH}_{4}{ }^{+}-\mathrm{N}\right)$ was measured via indophenol blue colorimetry. Soil nitrate nitrogen $\left(\mathrm{NO}_{3}{ }^{-} \mathrm{N}\right)$ was measured via disulfonic acid colorimetry ${ }^{39}$.

\section{Soil DNA extraction, nosZ gene amplification and quantitative fluorescence PCR (qfPCR)}

Soil DNA extraction was conducted using the E.Z.N.A. ${ }^{\circledR}$ soil DNA kit (OMEGA, GA, USA) according to the manufacturer's instruction, using approximately $0.5 \mathrm{~g}$ of fresh soil. The purity and integrity of the extracted DNA were assessed via 1\% agarose gel electrophoresis, and the concentration and purity of the extracted DNA were evaluated with the help of a nucleic acid quantometer (NanoDrop ND-1000). The nosZ gene were amplified using a primer set: nosZ-F(5'-GGGCTBGGGCCRTTGCA-3') and nosZ-R(5'GAAGCGRTCCTTSGARAACTTG-3') ${ }^{40}$. The volume of the PCR reaction mixture was $25 \mu \mathrm{L}$, containing 5.0 $\mu \mathrm{L} 10 \times$ ExTaq, $2.0 \mu \mathrm{L}$ dNPT $\left(2.5 \mu \mathrm{mol} \cdot \mathrm{L}^{-1}\right), 1.0 \mu \mathrm{Lforward}$ and reverse primer $\left(10 \mu \mathrm{mol} \cdot \mathrm{L}^{-1}\right), 2.0 \mu \mathrm{LDNA}$ template (1-10 ng), $0.25 \mu \mathrm{L}$ ExTaq (5U $\left.\mu \mathrm{L}^{-1}\right)$ and balanced ultrapure water $\left(\mathrm{ddH}_{2} \mathrm{O}\right)$. The PCR amplification conditions were as follows: predegeneration for $5 \mathrm{~min}$ at $94^{\circ} \mathrm{C}, 32$ cycles of amplification at 
$94^{\circ} \mathrm{C}$ for $30 \mathrm{~s}, 57^{\circ} \mathrm{C}$ for $45 \mathrm{~s}$, and $72^{\circ} \mathrm{C}$ for $55 \mathrm{~s}$, and extension at $72^{\circ} \mathrm{C}$ for $10 \mathrm{~min}^{41}$. After the PCR product was purified and recovered, it was ligated to the pMD8-T vector, and transformed into E. coli DH5a competent cells. After cultivation, the positive clones were picked and the nos $Z$ gene recombinant plasmid was extracted. The plasmid concentration was determined by a nucleic acid quantifier, and the copy number of the gene was calculated. The ten-fold serial dilutions were prepared to a gene copy number of $10^{3} \sim 10^{8}$, followed by standard curve preparation.

\section{High-throughput Sequencing}

After the amplification of the PCR products, the samples were sent to Shanghai Personalbio Technology Co., Ltd. for sequencing with an Illumina MiSeq System. After the raw reads were available, according to the barcodes sequences and primers sequences, the effective reads were screened. Then the barcodes and primers sequences were trimmed off. FLASH was used to merge the paired-end reads that passed the quality preliminary screening based upon their overlapping regions. At the same time USEARCH software was used to check and remove chimeras to obtain high-quality effective sequences. The uclust tool of QIIME was applied to align sequences, the operational taxonomic units (OTUs) were clustered at a similarity threshold of $97 \%$, and the most abundant sequence would serve as the representative sequence of the corresponding OTU. QIIME was further used to compare the representative sequences of OUT with the Functional Gene Pipeline (FunGene) to obtain taxonomic information of each OTU.

\section{Data analysis}

SPSS21.0 was used to conduct the statistical significance analysis and correlation analysis of soil chemical properties, a-diversity index and abundance of denitrifiers, and relative abundance of community composition. $\mathrm{R}$ was used to perform principal component analysis (PCA) and redundancy analysis.

\section{Declarations}

\section{Acknowledgements}

We thank all the authors for their contributions to this study. We would like to thank Maple for the English language revision.

\section{Funding}

This study was supported by the Science and Technology Foundation of Guizhou Province (No. [2016]7306, [2018]2337).

\section{Author contributions}


H.Z and Z.Y.T. conceived and designed the experiments; H.Z and Z.Y.T. performed the experiments; H.Z analyzed the date and wrote the manuscript.

\section{Competing interests}

The authors declare no competing interests.

Publisher's note: Springer Nature remains neutral with regard to jurisdictional claims in published maps and institutional affiliations.

\section{References}

1. Hu, W., Zhang, Y., Huang, B. \& Teng, Y. Soil environmental quality in greenhouse vegetable production systems in eastern China: Current status and management strategies. Chemosphere. 170, 183-195. https://doi:10.1016/j.chemosphere.2016.12.047 (2017).

2. Matlou, M. C. \& Haynes, R. J. Soluble organic matter and microbial biomass $\mathrm{C}$ and $\mathrm{N}$ in soils under pasture and arable management and the leaching of organic $\mathrm{C}, \mathrm{N}$ and nitrate in a lysimeter study. Applied. Soil Ecology, 34, 160-167 https://doi.org/https://doi:10.1016/j.apsoil.2006.02.005 (2006).

3. Bowden, R. D., Davidson, E., Savage, K., Arabia, C. \& Steudler, P. Chronic nitrogen additions reduce total soil respiration and microbial respiration in temperate forest soils at the Harvard Forest. Forest. Ecol Manag, 196, 43-56 https://doi.org/https://doi:10.1016/j.foreco.2004.03.011 (2004).

4. Enwall, K., Philippot, L. \& Hallin, S. Activity and composition of the denitrifying bacterial community respond differently to long-term fertilization. Appl. Environ Microbiol, 71, 8335-8343 https://doi.org/https://doi:10.1128/AEM.71.12.8335-8343.2005 (2005).

5. Tang, Y. et al. Impacts of nitrogen and phosphorus additions on the abundance and community structure of ammonia oxidizers and denitrifying bacteria in Chinese fir plantations. Soil Biol. Biochem, 103, 284-293 https://doi.org/https://doi:10.1016/j.soilbio.2016.09.001 (2016).

6. Yaganza, E. S., Rioux, D., Simard, M., Arul, J. \& Tweddell, R. J. Ultrastructural alterations of Erwinia carotovora subsp. atroseptica caused by treatment with aluminum chloride and sodium metabisulfite. Appl. Environ Microbiol, 70, 6800-6808 https://doi.org/https://doi:10.1128/AEM.70.11.6800-6808.2004 (2004).

7. Bauhus, J. \& Khanna, P. K. Carbon and nitrogen turnover in two acid forest soils of southeast Australia as affected by phosphorus addition and drying and rewetting cycles. Biol. Fert. Soils, 17 (3), 212-218 https://doi.org/https://doi:10.1007/BF00336325 (1994).

8. Liu, C., Dong, Y., Sun, Q. \& Jiao, R. Soil Bacterial Community Response to Short-Term Manipulation of the Nitrogen Deposition Form and Dose in a Chinese Fir Plantation in Southern China. Water. Air. Soil. Poll, 227, 447-458 https://doi.org/https://doi:10.1007/s11270-016-3152-0 (2016).

9. Yang, Y. D., Song, R. K., Ma, J. Y. \& Zeng, Z. H. Efects of long-term different $N$ and $P$ fertilization rates on the abundance of bacteria nitrifyng and denitrifying microorganisms in soil.J China. Agr. Univ.23(09),87-94. https://doi:10.11841/j.issn.1007-4333.2018.09.10(2018). 
10. Zhang, Y. et al. An integrated study to analyze soil microbial community structure and metabolic potential in two forest types. PLoS One, 9, e93773 https://doi.org/https://doi:10.1371/journal.pone.0093773 (2014).

11. King, D. \& Nedwell, D. B. The influence of nitrate concentration upon the end-products of nitrate dissimilation by bacteria in anaerobic salt marsh sedimen.FEMS. Microbiol. Ecol.1(1),23-28. https://10.1111/j.1574-6968.1985.tb01127.x(1985).

12. Lu, R. K. Soil and Agrochemical Analytical Methodspp: 227-448(Agricultural Science and Technology Press, Beijing, China, 1999).

13. Chen, Z. et al. Influence of fertilisation regimes on a nosZ-containing denitrifying community in a rice paddy soil. J. Sci. Food. Agric, 92, 1064-1072 https://doi.org/https://doi:10.1002/jsfa.4533 (2012).

14. Kloos, K., Mergel, A., Rosch, C. \& Bothe, H. Denitrification within the genus Azospirillum and other associative bacteria. Funct. Plant Biol, 28 (9), 991-998 https://doi.org/https://doi:10.1524/stnd.2009.1026 (2001).

15. Domeignoz-Horta, L. A. et al. Non-denitrifying nitrous oxide-reducing bacteria - An effective N2O sink in soil. Soil Biol. Biochem. 103, 376-379. https://doi:10.1016/j.soilbio.2016.09.010 (2016).

16. Chen, X. B., Zhu, D., Zhao, C., Zhang, L., Chen, L. \& Duan, W. Structure and diversity of soil nosZ-Type denitrifying microbial community in different types of Pinus koraiensis forests in Liangshui National Nature Reserve. Scientia. Sillvae Sinicae. 55(08), 106-117. https://doi :10.11707/j. 1001-7488. 20190812(2019).

17. Dandie, C. E. et al. Changes in bacterial denitrifier community abundance over time in an agricultural field and their relationship with denitrification activity. Appl. Environ Microbiol 74, 5997-6005. https://doi:10.1128/AEM.00441-08 (2008).

18. Song, M. Y., Li, Z., Wu, M., Liu, M. \& Jiang, C. Changes in soil microbial biomass and community structure with cultivation chronosequence of greenhouse vegetables. Scientia. Agr Sinica . 48(018), 3635-3644. https://doi:10.3864/j.issn.0578-1752.2015.18.007 (2015).

19. Wang, X. X., Chen, Y., Wang, J., Zuo, Q. \& Xiao, Q. Effects of vegetable planting ages on the physical and chemical and biological properties of greenhouse soils in Beijing. J. Plant Nutrition and Fertilizers. 24(06), 209-219. https://doi:10.11674/zwyf.18253(2018).

20. Liu, Y., Liu, X., Feng, Y., Yu, D. \& Shi, X. Composition of a Soil Organic Carbon Increment under Different Vegetable Cultivation Patterns: A Study Using Three SOC Pools. Sustainability. 11, 1-12. https://doi:10.3390/su11010035 (2018).

21. Wang, Y. et al. Quantification of net carbon flux from plastic greenhouse vegetable cultivation: a full carbon cycle analysis. Environ Pollut. 159, 1427-1434. https://doi:10.1016/j.envpol.2010.12.031 (2011).

22. Song, Y. et al. Long-Term Plastic Greenhouse Cultivation Changes Soil Microbial Community Structures: A Case Study. J. Agric Food Chem. 66, 8941-8948. https://doi:10.1021/acs.jafc.8b01829 (2018). 
23. Gao, X. H., Zhang, Y. P., Liu, Z. H., Jiang, L. H., Lin, H. T., Shi, J., Liu, P. \& Li, Y. Effects of cultivating years on soil ecological environment in greenhouse of Shouguang City, Shandong province. Acta Ecologica Sinica. 35( 5), 1452-1459. https://doi:10.5846/ stxb201305070963(2015).

24. Yang, L. et al. The impact of greenhouse vegetable farming duration and soil types on phytoavailability of heavy metals and their health risk in eastern China. Chemosphere. 103, 121130. https://doi:10.1016/j.chemosphere.2013.11.047 (2014).

25. Hallin, S., Jones, C. M., Schloter, M. \& Philippot, L. Relationship between N-cycling communities and ecosystem functioning in a 50-year-old fertilization experiment. ISME J. 3, 597-605. https://doi:10.1038/ismej.2008.128 (2009).

26. Tian, H., Yang, L. Q., Cao, W. C., Wang, Y., Zhu, Y., Chen, G. Z., Zhao, L. P., Wang, J. G. \& Zhang, X. J. Comparison of microbial communities and denitrifying gases emissions between the soils from a greenhouse and nearby farmland. Microbiology China. 42(5), 83-844. https://doi:10.13344/j.microbiol.china.141025 (2015).

27. Bergaust, L., Mao, Y., Bakken, L. R. \& Frostegard, A. Denitrification response patterns during the transition to anoxic respiration and posttranscriptional effects of suboptimal $\mathrm{pH}$ on nitrous [corrected] oxide reductase in Paracoccus denitrificans. Appl. Environ Microbiol. 76, 6387-6396. https://doi:10.1128/AEM.00608-10 (2010).

28. Menyailo, O. V. \& Huwe, B. Activity of denitrification and dynamics of N2O release in soils under six tree species and grassland in central siberia. J. Plant Nutr. Soil Sc. 162(5), 533-538. https://10.1002/(SICl)1522-2624(199910)162:5<533::AID-JPLN533>3.0.C0;2-B(1999).

29. Matlou, M. C. \& Haynes, R. J. Soluble organic matter and microbial biomass $C$ and $N$ in soils under pasture and arable management and the leaching of organic $\mathrm{C}, \mathrm{N}$ and nitrate in a lysimeter study. Applied. Soil Ecology. 34, 160-167. https://doi:10.1016/j.apsoil.2006.02.005 (2006).

30. Bowden, R. D., Davidson, E., Savage, K., Arabia, C. \& Steudler, P. Chronic nitrogen additions reduce total soil respiration and microbial respiration in temperate forest soils at the Harvard Forest. Forest. Ecol Manag. 196, 43-56. https://doi:10.1016/j.foreco.2004.03.011 (2004).

31. Enwall, K., Philippot, L. \& Hallin, S. Activity and composition of the denitrifying bacterial community respond differently to long-term fertilization. Appl. Environ Microbiol. 71, 8335-8343. https://doi:10.1128/AEM.71.12.8335-8343.2005 (2005).

32. Tang, Y. et al. Impacts of nitrogen and phosphorus additions on the abundance and community structure of ammonia oxidizers and denitrifying bacteria in Chinese fir plantations. Soil Biol. Biochem. 103, 284-293. https://doi:10.1016/j.soilbio.2016.09.001 (2016).

33. Yaganza, E. S., Rioux, D., Simard, M., Arul, J. \& Tweddell, R. J. Ultrastructural alterations of Erwinia carotovora subsp. atroseptica caused by treatment with aluminum chloride and sodium metabisulfite. Appl. Environ Microbiol. 70, 6800-6808. https://doi:10.1128/AEM.70.11.68006808.2004 (2004).

34. Bauhus, J. \& Khanna, P. K. Carbon and nitrogen turnover in two acid forest soils of southeast Australia as affected by phosphorus addition and drying and rewetting cycles. Biol. Fert. Soils. 17(3), 
212-218. https://doi:10.1007/BF00336325(1994).

35. Liu, C., Dong, Y., Sun, Q. \& Jiao, R. Soil Bacterial Community Response to Short-Term Manipulation of the Nitrogen Deposition Form and Dose in a Chinese Fir Plantation in Southern China. Water. Air. Soil. Poll. 227, 447-458. https://doi:10.1007/s11270-016-3152-0 (2016).

36. Yang, Y. D., Song, R. K., Ma, J. Y. \& Zeng, Z. H. Efects of long-term different N and P fertilization rates on the abundance of bacteria nitrifyng and denitrifying microorganisms in soil. J China. Agr. Univ. 23(09), 87-94. https://doi:10.11841/j.issn.1007-4333.2018.09.10(2018).

37. Zhang, Y. et al. An integrated study to analyze soil microbial community structure and metabolic potential in two forest types. PLoS One. 9, e93773. https://doi:10.1371/journal.pone.0093773 (2014).

38. King, D. \& Nedwell, D. B. The influence of nitrate concentration upon the end-products of nitrate dissimilation by bacteria in anaerobic salt marsh sedimen. FEMS. Microbiol. Ecol. 1(1), 23-28. https://10.1111/j.1574-6968.1985.tb01127.x(1985).

39. Lu, R. K. Soil and Agrochemical Analytical Methods, pp: 227-448. Beijing, China: Agricultural Science and Technology Press (1999).

40. Chen, Z. et al. Influence of fertilisation regimes on a nosZ-containing denitrifying community in a rice paddy soil. J. Sci. Food. Agric. 92, 1064-1072. https://doi:10.1002/jsfa.4533 (2012).

41. Kloos, K., Mergel, A., Rosch, C. \& Bothe, H. Denitrification within the genus Azospirillum and other associative bacteria. Funct. Plant Biol. 28(9), 991-998. https://doi:10.1524/stnd.2009.1026(2001).

\section{Figures}




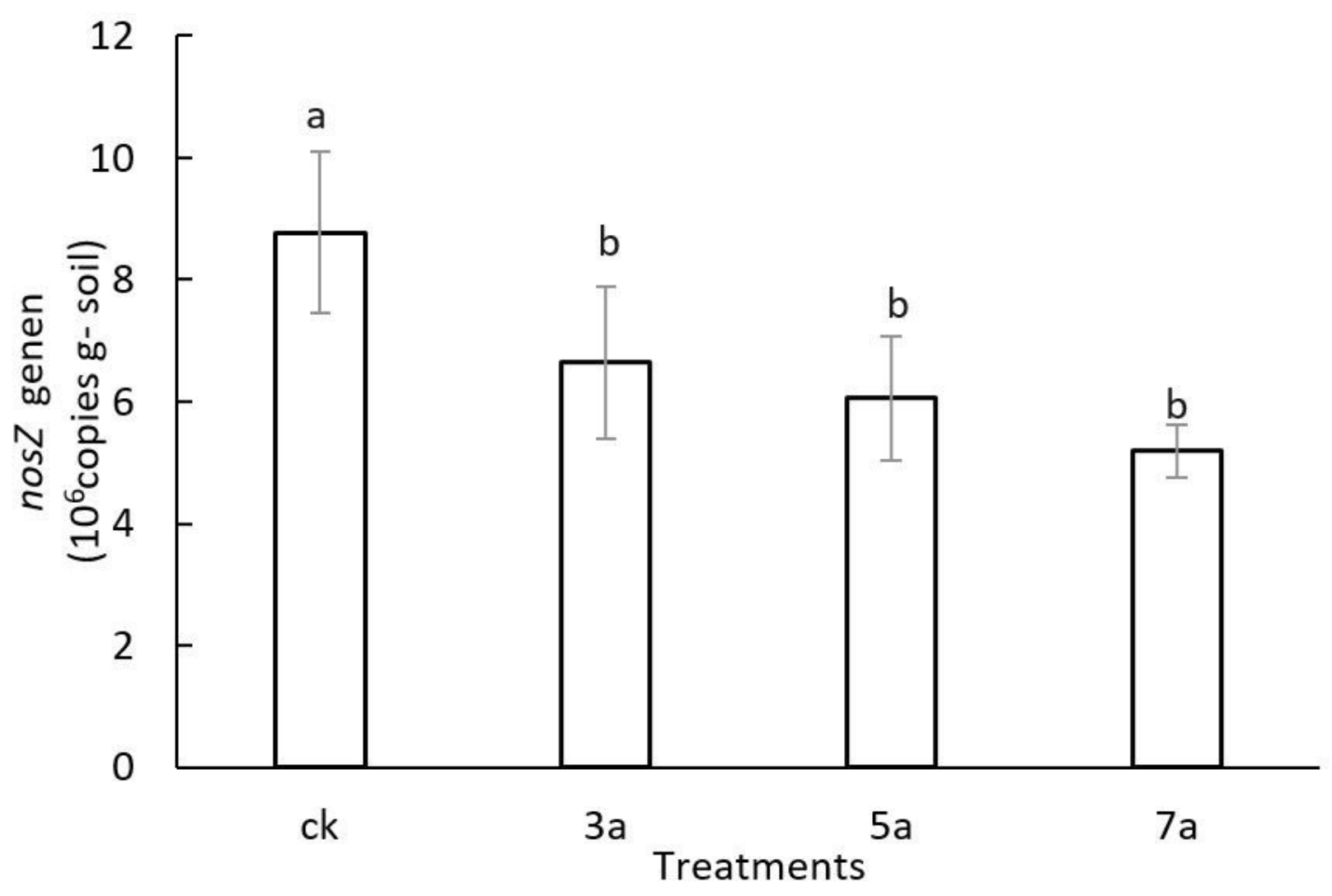

Figure 1

Abundance of nosZ genes with cultivation age of greenhouse vegetables. 


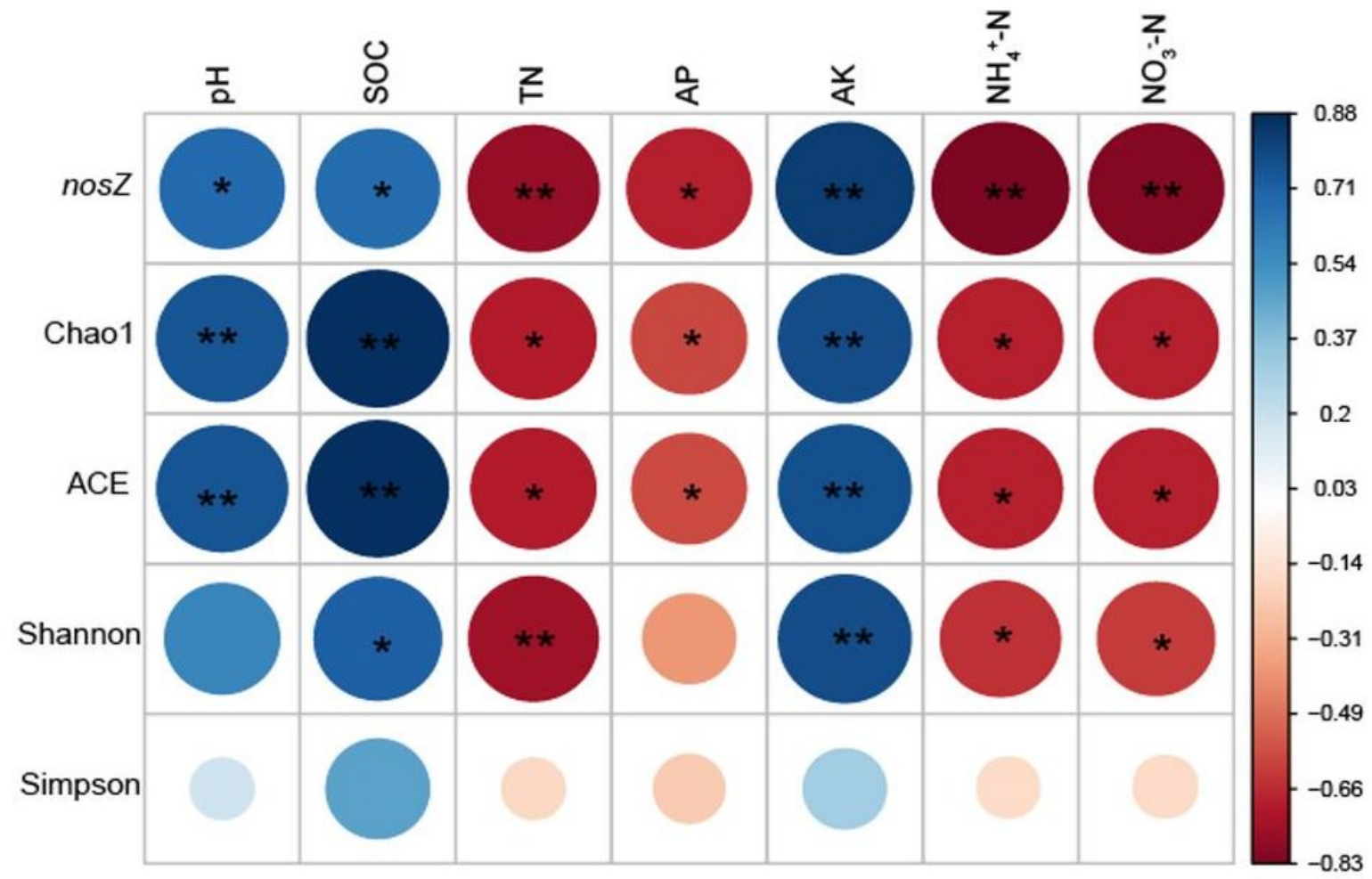

Figure 2

Correlation analysis between nosZ genes abundance, diversity index and soil chemical properties 


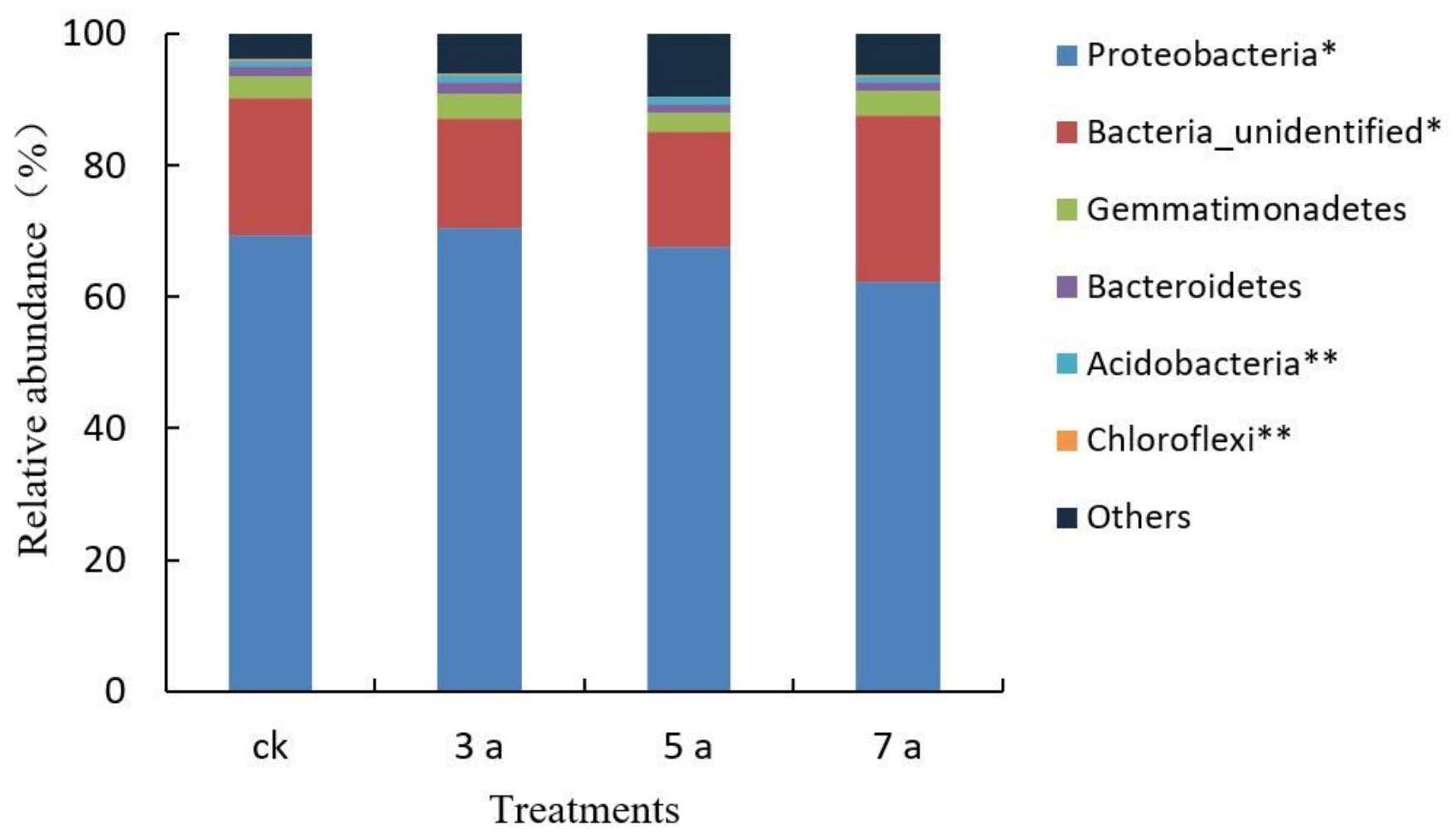

Figure 3

Phylum composition of nosZ-type denitrifying bacterial community with cultivation age of greenhouse vegetables treatments. * and ${ }^{* *}$ indicate a signifcance diference at 0.05 and 0.01 levels, respectively. 


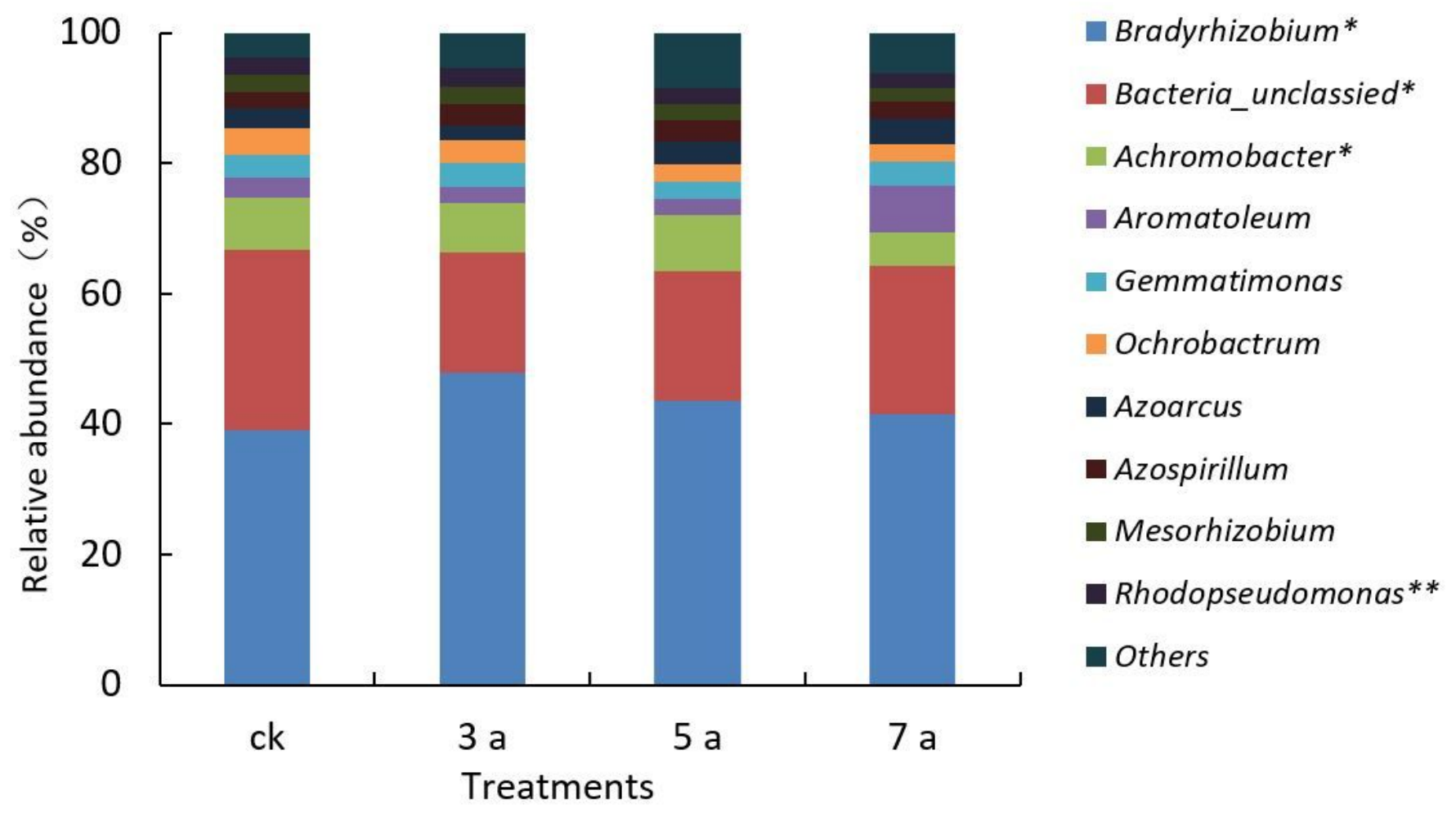

Figure 4

Genus composition of nosZ-type denitrifying bacterial community with cultivation age of greenhouse vegetables treatments. * and $* \star$ indicate a signifcance diference at 0.05 and 0.01 levels, respectively. 


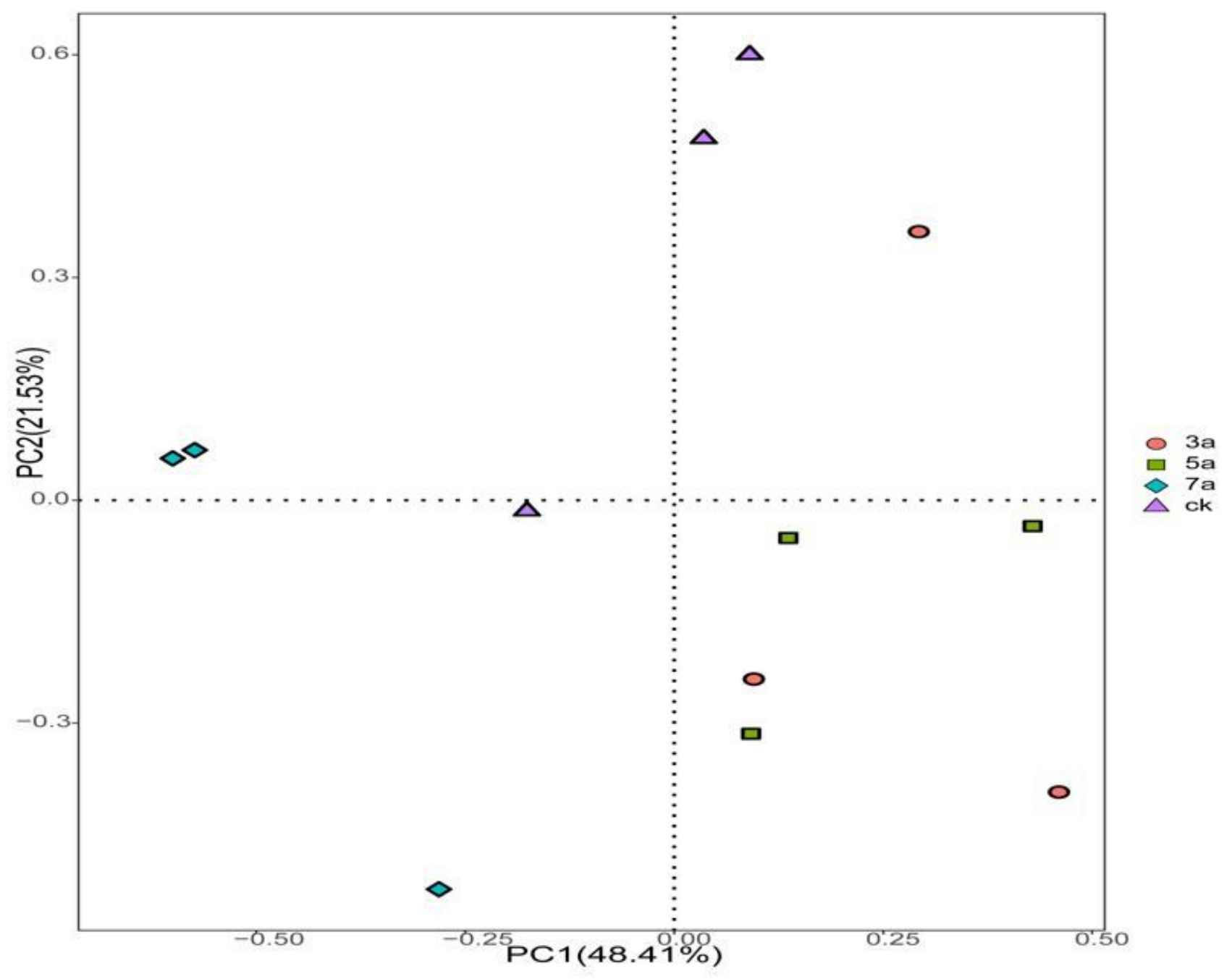

Figure 5

Principal components analysis of nosZ-type denitrifying bacterial community with cultivation age of greenhouse vegetables. 


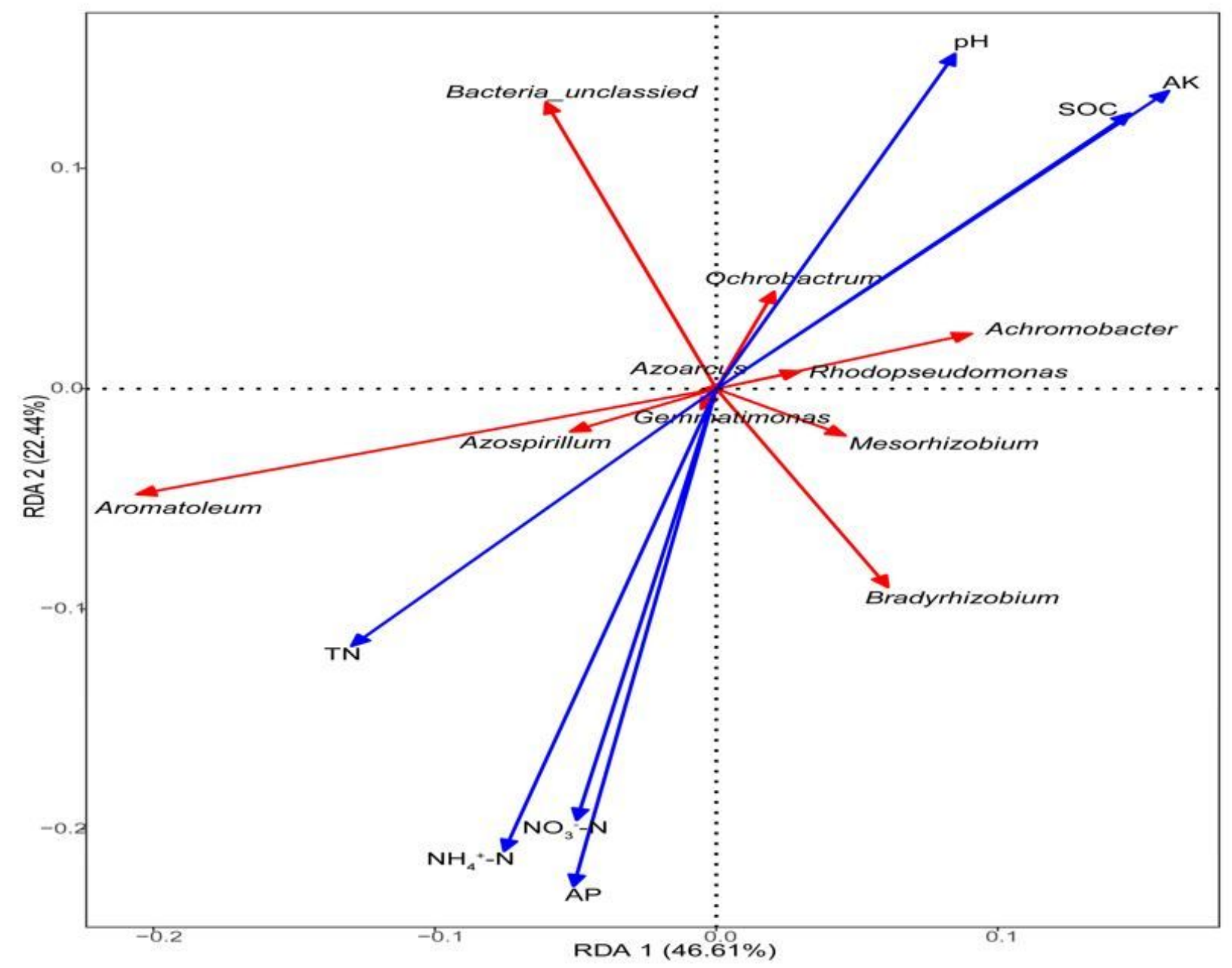

Figure 6

Redundancy analysis (RDA) of relationships among the nosZ communities and soil chemical properties 